\title{
PACYFIZM I ANTYMILITARYZM W EUROPIE ZACHODNIEJ W LATACH 1918-1939
}

(D) http://orcid.org/0000-0001-7142-6170

\section{Remigiusz Kasprzycki}

Uniwersytet Pedagogiczny im. Komisji Edukacji Narodowej w Krakowie

\section{ABSTRACT \\ PACIFISM AND ANTI-MILITARISM IN WESTERN EUROPE, 1918-1939}

As the consequence of the events of 1914-1918, the pacifism was on the rise in Western Europe. Societies of England, France and Germany as well as other Western European countries, set themselves the goal of preventing another war from breaking out. International congresses and conventions were organized. They were attended by peace advocates representing various social and political views, which made cooperation difficult. These meetings did not prevent the Spanish Civil War, the aggression against Abyssinia and the outbreak of World War II. In addition to moderate pacifists, Western Europe was also home to radical anti-militarists who believed that way to the world peace led through the abolition of military service. The pacifists in Britain and France were satisfied with their politicians' submissiveness and indecision toward Hitler during the 1930s. Pacifism and radical anti-militarism also fitted perfectly into the plans of the Comintern. With its help, the USSR weakened the military potential of Western Europe.

Keywords: pacifism, antimilitarism, Great Britain, Germany, France, Western Europe.

Słowa kluczowe: pacyfizm, antymilitaryzm, Wielka Brytania, Niemcy, Francja, Europa Zachodnia.

\section{WSTEP}

I wojna światowa była dla społeczeństw zachodnich traumą. Jak słusznie zauważył Andrzej Chwalba, „,nawet ci, którzy wygrali, w istocie byli przegranymi”'. Konsekwencją krwawej wojny był ponowny wzrost popularności haseł pacyfistycznych oraz antymilitarystycznych, i to nie tylko wśród przegranych, ale także wśród

${ }^{1}$ A. Chwalba, Samobójstwo Europy. Wielka Wojna 1914-1918, Kraków 2014, s. 622. 
zwycięzców. Pacyfizm odrodził się po 1918 roku z dużą siłą przede wszystkim w takich krajach jak Wielka Brytania, Niemcy i Francja. O pacyfizmie u progu 1914 roku, a także w latach 1914-1918 w wymienionych krajach napisano bardzo wiele. W przypadku Wielkiej Brytanii kluczowe są obszerna Autobiografia Bertranda Russella z 1969 roku, książki autorstwa Petera Brocka i monografia Martina Ceadela². Niemiecki pacyfizm sprzed I wojny światowej i w jej trakcie opisał zaś w 1993 roku Karol Fiedor ${ }^{3}$. W 2016 roku losy francuskiego pacyfizmu przed Wielką Wojną interesująco przybliżył zaś polskiemu czytelnikowi Rafał Dobek ${ }^{4}$.

Celem mojego artykułu jest nie tylko opisanie losów pacyfizmu i antymilitaryzmu w międzywojennych krajach Europy Zachodniej. Interesowała mnie również międzynarodowa współpraca pacyfistów z Niemiec, Francji i Wielkiej Brytanii. Stawiam tezę, że takie kontakty nie przyniosły wymiernych korzyści, nie zapobiegły żadnemu konfliktowi zbrojnemu w międzywojniu, a także wybuchowi II wojny światowej. Zakładam, że rozwój zachodnioeuropejskiego pacyfizmu i antymilitaryzmu leżał w interesie Związku Sowieckiego, a po 1933 roku również III Rzeszy. Szlachetne zaangażowanie zachodnich pacyfistów w obronę pokoju przez Kreml i Reichstag było więc traktowane jako działania tzw. pożytecznych idiotów. Ze względu na ograniczenia ramowe artykułu w wielu kwestiach tylko sygnalizuję swoje rozważania.

\section{WIELKA BRYTANIA}

W Wielkiej Brytanii po 1918 roku pojawiła się poważna niechęć wobec instytucji wojska. O doprowadzenie do okrutnej rzezi na zachodnim froncie obwiniano zwłaszcza dowództwo. Społeczeństwo brytyjskie uważało, że za wszelką cenę nie wolno dopuścić do rozpętania nowej wojny. Konsekwencją był drastyczny spadek chętnych do służby w armii. W kolejnych latach brakowało nie tylko odpowiednich kandydatów do służby wojskowej, przyszłych żołnierzy szeregowych, ale także nowego, profesjonalnie wykształconego korpusu oficerskiego. Młodzi Brytyjczycy nie wiązali swojej przyszłości z wojskiem, oficerowie byli wyszydzani. Po I wojnie światowej narodził się w brytyjskim społeczeństwie stereotyp zawodowego oficera, tzw. Colonela-Blimpa, czyli wojskowego szowinisty ${ }^{5}$. Negatywny wizerunek nie tylko oficerów, ale i wojska w ogóle sprawił, że pokolenie brytyjskich rekrutów nie miało wobec wojskowych przełożonych żadnego szacunku, ci zaś, świadomi braku autorytetu, rezygnowali z wydawania trudnych rozkazów. Bojąc się niesubordynacji albo buntu młodych żołnierzy, wybierali negocjacje i perswazję. Najbardziej roszczeniowi byli

${ }^{2}$ M. Caedel, Pacifism in Britain, 1914-45. Defining of a Faith, Oxford 1980.

3 K. Fiedor, Niemiecki ruch obrońców pokoju, Wrocław 1993.

${ }^{4}$ R. Dobek, Pacyfizm francuski 1871-1914 [w:] Jan Bloch, pacyfizm europejski i wyobraźnia Wielkiej Wojny, Studia i rozważania, red. M. Kornat, Warszawa 2016.

${ }^{5}$ G.P. Megarge e, The Army before Last: British Military Policy, 1919-1939, and Its Relevance for the U.S Army Today, Santa Monica 2000, s. 8-12. 
żołnierze z miast, a tego typu postawy dodatkowo wzmocniło zniesienie w kwietniu 1930 roku kary śmierci za bunt i dezercję. Brak woli służenia w armii obserwowano wśród młodzieży inteligenckiej i robotniczej. Ważną rolę w tym procesie odgrywali nauczyciele, którzy przekonywali młodych ludzi, że wojsko zmarnuje ich życie. Przywrócenie przymusowego poboru do armii brytyjskiej, który wprowadzono w 1916 roku i zniesiono w 1920 roku, było nie do pomyślenia. Przeprowadzone w styczniu 1937 roku badania opinii publicznej wykazały, że społeczeństwo brytyjskie jest zdecydowanie przeciwne jego ponownemu wprowadzeniu ${ }^{6}$. Niechęć Brytyjczyków do instytucji armii dostrzegli już w pierwszej połowie lat 20. Polacy, między innymi Roman Dyboski, znany przedwojenny anglista i znawca Wielkiej Brytanii. W 1924 roku Dyboski pisał o powszechnym, masowym i tzw. zawziętym angielskim antymilitaryzmie ${ }^{7}$. Niechęć wobec służby wojskowej nie zmniejszyła się nawet w obliczu groźby wybuchu II wojny światowej. Tak było 27 kwietnia 1939 roku, kiedy przywrócono częściowy pobór wojskowy, a nawet 3 września 1939 roku, kiedy stał się powszechny i obowiązkowy, nadal wielu odmawiało pełnienia służby. Bycie obdżektorem wciąż było modne, chociaż sami odmawiający często nie wiedzieli, czym właściwie jest pacyfizm ${ }^{8}$.

W opinii Petera Brocka i Nigela Younga, badaczy pacyfizmu, bastionem tego ruchu po I wojnie światowej stała się Wielka Brytania. Zaangażowali się w niego nie tylko lewicowi intelektualiści, jak we Francji i Niemczech, ale także robotnicy. 12 sierpnia 1920 roku brytyjscy robotnicy zagrozili, że jeśli brytyjski rząd poprze Polskę w wojnie z Rosją bolszewicką, w kraju rozpocznie się strajk generalny. Niechęć wobec militaryzmu wspierali również lewicowi politycy brytyjskiej Partii Pracy, którzy należeli do organizacji Union of Democratic Control (UDC). Na czele 15-osobowej grupy UDC stał angielski polityk Arthur Ponsonby, który w październiku 1924 roku napisał list do prasy. Wezwał w nim społeczeństwo do odmawiania służby w czasie wojny i sprzeciwiania się militarnym zapędom rządu. Stwierdził, że w cywilizowanym świecie agresja nie może być przyczyną wojen, dowodził, że poprzez bezpośrednie negocjacje lub formy arbitrażu da się pokojowo rozwiązać wszystkie spory między narodami. Inicjatywę rozpropagowała w społeczeństwie UDC. Do grudnia 1925 roku aż 40000 osób złożyło pisemne przyrzeczenie, w którym zadeklarowało odmowę służby wojskowej w czasie wojny i sprzeciw wobec podejmowania militarnych kroków przez władzę. W 1926 roku w londyńskiej Albert Hall odbył się potężny wiec związkowy, podczas którego Ernest Bevin, lider The Transport and General Workers' Union, największego związku zawodowego w Wielkiej Brytanii, wyraził swoje przywiązanie do pacyfizmu? ${ }^{9}$. Warto jednak pamiętać, że Bevin był zdecydowanym antykomunistą i wrogiem Związku Sowieckiego, czego nie można powiedzieć o wszystkich brytyjskich pacyfistach. Wspomnianą antymilitarystyczną akcję UDC w 1927 roku poparł osobiście Ponsonby. 8 grudnia

${ }^{6}$ D. French, Armia Brytyjska 1919-1945, tłum. R. Majewski, Poznań 2014, s. 19, 51-53.

7 R. Dyboski, Anglia po wojnie. Wrażenia i refleksje, Kraków 1924, s. 53.

${ }^{8}$ P. Brock, B. de Ligt-Fonds, Overdenkingen Bij Het Herlezen Van ,La Paix Crétrice” Na 51 Jaar. Reflections on reading „La Paix Crétrice” after fifty-one years, Zwolle 1994, s. 19.

9 P. Brock, N. Young, Pacifism in the Twentieth Century, Syracuse 1999, s. 118-119. 
1927 roku wręczył brytyjskiemu premierowi petycję z podpisami 128700 osób, które deklarowały odmowę służby wojskowej w czasie wojny i sprzeciw wobec podejmowania militarnych kroków przez władzę ${ }^{10}$. Związkowcy i lewicowi politycy doskonale wpisywali się we wspomniany nastrój niechęci do instytucji wojska.

Nic więc dziwnego, że to właśnie w Londynie odbył się I Międzynarodowy Kongres Pacyfistyczny. Na kilka dni - od 24 do 29 lipca 1922 roku - do Anglii przybyły organizacje pacyfistyczne z całego świata. Pod szczególną obserwacją znajdowała się delegacja niemiecka; zastanawiano się, czy Niemcy, reprezentowani na londyńskim kongresie przez Deutsches Friedens-Kartell (DFK; Niemiecki Kartel Pokoju), będą równie mocno jak inne delegacje zaangażowani w pracę nad utrwaleniem nowo ustanowionego ładu powersalskiego ${ }^{11}$. Kongres londyński potwierdzał pacyfistyczne tendencje w Europie Zachodniej. Na początku sierpnia 1919 roku powstała niemiecka akcja Nie-wieder-Krieg, (Nigdy więcej wojny), a w 1921 roku w Wielkiej Brytanii utworzono No More War Movement NMWM - (Ruch Sprzeciwu Wojnie). Nie sposób wymienić wszystkich organizacji w Wielkiej Brytanii, które po I wojnie światowej postawiły sobie za cel zwalczanie militaryzmu. Ich popularność potwierdza także szybki wzrost liczby ich członków. Przykładowo Peace Pledge Union (PPU) w niedługim czasie od powstania w październiku 1934 roku liczyła 135000 członków $^{12}$. W 1937 PPU połączyła się z NMWM. Ruchy pacyfistyczno-antymilitarystyczne w Wielkiej Brytanii tworzyli związkowcy, religijni kwakrzy i katolicy skupieni wokół Erica Gilla. Silnie wspierali go lewicujący pisarze i filozofowie. Ich poglądy ulegały pewnej ewolucji, czego przykładem był Bertrand Russell, znacznie mniej radykalny niż w czasie I wojny światowej. W marcu 1931 roku Russell w jednym z listów do Runhama Browna pisał, że znacznie więcej w sprawie gwarancji światowego pokoju spodziewa się po międzynarodowych organizacjach niż po działaniach poszczególnych pacyfistów ${ }^{13}$. Swoje poglądy zrewidował również Aldous Huxley, który tuż po zakończeniu wielkiej wojny propagował ideę non-violence Gandhiego, a w późnych latach 30 . był już o wiele bardziej sceptyczny wobec stosowania biernego oporu ${ }^{14}$. Optowanie Huxleya na rzecz non-violence wywarło duże wrażenie na amerykańskim działaczu pacyfistycznym Richardzie B. Greggu, byłym prawniku, który nawrócił się na kwakryzm, a także holenderskim anarchiście Barcie de Ligt. Ten ostatni twierdził, że idea Gandhiego może zostać spożytkowana do rewolucji społecznej ${ }^{15}$, w swoich pismach wzywał do masowego bojkotu służby wojskowej. Koncepcje kontestacji armii, a przede wszystkim zapobieżenia wybuchowi wojny Ligt rozwinął w powstałym w 1934 roku planie pokojowym „The Conquest of Violence”, do którego wstęp napisał właśnie Aldous Huxley. Ligt, określany jako

${ }^{10}$ K. Fiedor, Działalność organizacji pacyfistycznych $w$ Europie na rzecz rozbrojenia i zachowania pokoju w okresie międzywojennym, „Acta Universitatis Lodziensis” 1986, t. 28, s. 150.

${ }^{11}$ K. Fiedor, Niemiecki ruch..., s. 215.

12 The Moot Papers: Faith, Freedom and Society 1938-1944, ed. K. Clements, New York 2010, s. 303 .

${ }^{13}$ B. Russel, Autobiografia 1914-1944, thum. A. Podzielna, Warszawa 1998, s. 279.

${ }_{14}^{14}$ P. Brock, N. Young, Pacifism..., s. 115-116.

15 Ibidem, s. 116. 
"Gandhi Zachodu”, wywarł ogromny wpływ na ruch pacyfistyczny w Wielkiej Brytanii, Stanach Zjednoczonych i Republice Weimarskiej. Jego największa aktywność na międzynarodowej scenie pacyfistycznej i antymilitarystycznej przypadła na lata 1928-1934 ${ }^{16}$. Znanym przeciwnikiem militaryzmu i nieskrępowanego rozwoju armii w Wielkiej Brytanii był także John Beverley Nichols. Nie tylko negował on istniejący przy brytyjskich szkołach średnich Korpus Przeszkolenia Oficerskiego, sprzeciwiał się również budowie pomników upamiętniających czas wojny ${ }^{17}$. Jeszcze radykalniejszy był Albert Einstein, który popierał wszystkich uchylających się od służby wojskowej. Twierdził on, że nacjonalizm rozwinął się najbujniej w tych krajach, gdzie została wprowadzona powszechna służba wojskowa, według niego należało zatem sprzeciwiać się obowiązkowej służbie w armii ${ }^{18}$. Krytykowano go, twierdzono, że marzenia o powszechnej realizacji odmowy służby wojskowej to utopia ${ }^{19}$. Hasła genialnego fizyka nie pozostały jednak bez echa - służyły za wzór prawdziwego, bezkompromisowego pacyfizmu, a właściwie już antymilitaryzmu. Szczególnie żywo dyskutowali o tym niemieccy antymilitaryści.

W większości jednak społeczeństwo brytyjskie dalekie było od negacji przeszkolenia wojskowego, burzenia pomników wojennych bohaterów czy deprecjonowania jakiejkolwiek form żołnierskiej służby. W tym kraju większość osób prezentowała umiarkowane poglądy pacyfistyczne i ceniła wartość pokojowego funkcjonowania świata. Dlatego też utożsamiano się przede wszystkim z League of Nations Union (LNU), którą założono już 13 października 1918 roku. LNU stawiała sobie za cel promowanie międzynarodowej sprawiedliwości, zbiorowego bezpieczeństwa i trwałego pokoju między narodami opartego na ideach powstałej 28 czerwca 1919 roku Ligi Narodów. W dwudziestoleciu międzywojennym LNU należała do największych i najbardziej wpływowych organizacji brytyjskiego ruchu pokojowego. W 1931 roku liczba osób związanych z tą organizacją przekroczyła 400 000, choć w 1939 roku straciła przeszło połowę członków ${ }^{20}$. Pacyfistyczne nastroje i oczekiwania społeczeństwa pokrywały się z kierunkami tutejszej sceny politycznej. W 1919 roku brytyjscy politycy nie mogli sobie pozwolić na fizyczne koszty kolejnej wojny. W latach 20. i 30. ochrona brytyjskich interesów fiskalnych przeważała nad interesem bezpieczeństwa. Wielka Brytania zaczęła prowadzić politykę izolacjonizmu i ograniczać wydatki mili$\operatorname{tarne}^{21}$. Niedopuszczenie do wybuchu kolejnej wojny Wielkiej Brytanii miała zapewnić

${ }^{16}$ N. Bock, Pazifizmus zwischen Anpassung und „freier Ordnung”, Friedensdiskussionen in Weimarer Republik und die Gewaltfreiheitstheorie des holländischen Pazifisten Bart de Ligt (1883-1938), Hamburg 1991, s. 73.

17 J.B. Nichols, Dzwon na trwoge, thum. W. Komarnicka, Warszawa 1934, s. 93-98, 241-244.

18 A. Einstein, Mój obraz świata, Warszawa 1935, s. 23, 68, 90-92, 102-103.

${ }^{19}$ L. Bauer, Jutro znowu wojna, badanie teraźniejszości, rzut oka w przyszłość, thum. W. Rogowicz, Warszawa 1932, s. 47.

${ }^{20}$ R. Davis, The British Peace Movement in the Interwar Years. Le Mouvement pacifiste britannique de l'entre-deux-guerres, „Revue Française de Civilisation Britannique. French Journal of British Studies" 2017, nr 3, https://journals.openedition.org/rfcb/1415 [dostęp: 14 V 2021 r.].

${ }_{21}$ J. Royo, British Military Decline 1919-1939, https://smallwarsjournal.com/jrnl/art/british-military-decline-1919-1939 [dostęp: 15 V 2021 r.]. 
polityka rozbrojenia, której kolejny etap stanowił appeasement ${ }^{22}$. Ustępstwa władz brytyjskich wobec Hitlera nie byłyby możliwe bez szerokiej akceptacji społecznej dla takiej polityki, której jedynym celem stało się utrzymanie za wszelką cenę światowego pokoju.

Appeasement pośrednio został wzmocniony przez wyniki referendum zorganizowanego na przełomie 1934 i 1935 roku przez LNU, w którym Brytyjczycy potwierdzili dezaprobatę dla włoskich planów podboju Etiopii. W powszechnym głosowaniu, w którym wzięło udział według różnych źródeł od 11,5 do 12 mln osób, obywatele brytyjscy odpowiedzieli także na pytania o członkostwo swojego kraju w Lidze Narodów, powszechną redukcję zbrojeń, powszechne zniesienie lotnictwa wojskowego i morskiego na drodze porozumienia międzynarodowego, a także zakaz sprzedaży broni i amunicji dla osiągnięcia zysku. W większości przypadków pozytywne odpowiedzi przekraczały $90 \%{ }^{23}$. To nietypowe głosowanie wywołało sporo kontrowersji i podejrzeń, ,[...] również zarzut, że miało ono ciche poparcie ze strony rządu przygotowującego się do istotnej zmiany polityki międzynarodowej w kierunku wyraźniejszej appeasement policy (polityka łagodzenia ustępstw)" - jak pisał Stanisław Sierpowski ${ }^{24}$. Takie sondaże były bardzo potrzebne. W rzeczywistości zdecydowana większość konserwatywnych polityków brytyjskich realizujących appeasement dystansowała się nawet od umiarkowanego LNU. Oficjalne, dość silnie pacyfistyczne nastroje społeczeństwa pomagały im jednak w pójściu na kolejne ustępstwa na rzecz Hitlera. Co gorsza, po przeciwnej stronie politycznego obozu nie istniał sprzeciw wobec takiej polityki. Donald Soper, teolog metodystyczny, a zarazem członek Partii Pracy, jeszcze w 1936 roku przekonywał, że ,istniała prawdziwa tęsknota za pokojem w krajach takich jak Włochy i Niemcy"25. Przypuszczalnie tacy pacyfiści budzili „szczerą sympatię” Hitlera.

\section{NIEMCY}

Wydawało się, że najdogodniej pacyfizm rozwinie się w powojennych Niemczech. W czasie wielkiej wojny działały tutaj takie organizacje, jak Deutsche Friedensgesellschaft, czyli DFG (Niemieckie Stowarzyszenie Pokoju), Bund Neues Vaterland (BNV; Związek Nowej Ojczyzny), Frauenausschuss für dauernden Frieden (Komitet Kobiecy na rzecz Zapewniania Trwałego Pokoju). Paradoksalnie jednak w tym kraju intensywniejsze działania grup pacyfistycznych napotykały poważny opór. W opinii Karola Fiedora nawet pewna część przeciwników zbrojeń w latach

${ }^{22}$ P. Kochanows ki, Analiza realizacji polityki zagranicznej państwa na przykładzie Wielkiej Brytanii czasu II wojny światowej. Fakty i mity, Torun 2018, s. 68.

${ }^{23}$ S. Sierpowski, Kondycja Stowarzyszeń Przyjaciót Ligi Narodów (1919-1939), Poznań 2018, s. 137.

${ }^{24}$ Ibidem, s. 138.

${ }^{25}$ R. Davis, The British Peace... 
1918-1919 głosiła, że konieczne jest utrzymanie w republice silnej armii ${ }^{26}$. Niemieccy pacyfiści szybko zrozumieli, że nie mając aż tak wielkiego poparcia społecznego, jak w Wielkiej Brytanii, powinni zacieśnić współpracę. Świadectwem takich dążeń był kongres niemieckich pacyfistów, który odbył się w czerwcu 1919 roku w Berlinie. Na berlińskim kongresie pacyfistów doszło jednak do rozbieżności w ocenie odpowiedzialności za wybuch wielkiej wojny. Jeden z obozów uznawał, że kajzerowskie Niemcy były głównym sprawcą rozpętania I wojny światowej, drugi zaś, że Niemcy są jedynie współwinni rozpoczęcia konfliktu ${ }^{27}$. Był to problem, który nasilił się w niemieckim ruchu pacyfistycznym zwłaszcza pod koniec lat 20. Ten podział bez wątpienia przyczynił się do słabości niemieckiego ruchu pacyfistycznego, nie przeszkodził jednak w szukaniu kompromisów, porozumienia, a co najważniejsze - scalaniu niemieckiego ruchu pacyfistycznego, do czego doszło w 1921 roku. W Republice Weimarskiej została powołana jedna silna organizacja pacyfistyczna. Był to wymieniony już wcześniej DFK, który stworzyły wszystkie najważniejsze niemieckie organizacje pacyfistyczne, w tym m.in. Deutsche Liga für Menschenrechte - DLfM (Niemiecka Liga Obrony Praw Człowieka) oraz Friedensbund Deutscher Katholiken - FDK (Związek Pokoju Niemieckich Katolików), a także wiele mniejszych związków i ruchów. W latach 1921-1925 w różne niemieckie organizacje pacyfistyczne zaangażowanych było w sumie 100000 osób $^{28}$. Wspólna reprezentacja niemieckich pacyfistów stanowiła całkiem pokaźną siłę. Współpraca ta pozwoliła na zorganizowanie w Berlinie jesienią 1924 roku wielkiego międzynarodowego kongresu pacyfistów.

Na czele DFK stanął Ludwig Quidde, który nadal pełnił funkcję przewodniczącego DFG, pacyfistycznej organizacji założonej jeszcze w 1892 roku. Quidde dla umiarkowanych niemieckich pacyfistów był autorytetem, jednak już wśród przedstawicieli lewego, antymilitarystycznego skrzydła nie cieszył się poważaniem. Radykalne skrzydło grupy DFG, na czele z generałem w stanie spoczynku Paulem Freiherrem von Schoenaichem i Fritzem Küsterem, otwarcie nawoływało do odmowy służby wojskowej w wypadku konfliktu zbrojnego ${ }^{29}$. Zagorzały pacyfista, emerytowany generał Berthold von Deimling, również członek DFG, a zarazem sygnatariusz opisanego dalej Międzynarodowego manifestu przeciwko obowiazkowej stużbie wojskowej z jesieni 1926 roku, dowodził zaś, że koszarowe życie, wojskowy dryl, ślepe posłuszeństwo, bezmyślne polecenia i cały system wojskowych ćwiczeń podważają szacunek do osobowości człowieka, demokracji i życia ludzkiego ${ }^{30}$. Z pewnością

${ }^{26}$ K. Fiedor, Militaryzmowi i faszyzmowi - nie. Carl von Ossietzky, życie i walka, WarszawaWrocław 1986, s. 36.

${ }^{27}$ Idem, Niemiecki ruch ..., s. 103.

${ }^{28}$ Idem, Militaryzmowi..., s. 37, 40.

${ }_{29}$ Archiwum Akt Nowych (dalej: AAN), Ambasada Rzeczypospolitej Polskiej w Berlinie, Pismo z 23 II 1929 r., sygn.1523, k. 15.

${ }^{30}$ K. Zirke1, Vom Militaristen zum Pazifisten: Politisches Leben und Wirken des Generals Berthold von Deimling vor dem Hintergrund der Entwicklung Deutschlands vom Kaiserreich zum Dritten Reich, Inaugural-Dissertation zur Erlangung des akademischen Grades eines Doktors der Philosophie (Dr. phil.) durch die Philosophische Fakultät der Heinrich-Heine-Universität Düsseldorf 2006, s. 390. 
wielu niemieckich oficerów przewartościowało swoje poglądy po doświadczeniu osobistego udziału w wielkiej wojnie.

Nie bez wpływu były również idee głoszone przez niemieckich pisarzy. Ewoluowały one od 1914 roku - apoteozy armii i czynu zbrojnego - do 1933 roku oraz skrajnego antymilitaryzmu i pacyfizmu. Po zakończeniu wielkiej wojny wielu niemieckich pisarzy, głęboko rozczarowanych wydarzeniami ostatnich lat, zamilkło. Nie było to jednak jednoznaczne z krytyką wojska; najsławniejsi niemieccy literaci, jak Tomasz Mann, byli wręcz wrogami pacyfizmu. W 1918 roku Mann napisał esej Rozważania człowieka apolitycznego. Zaatakował w nim pacyfistów, a także bronił wartości niemieckiej kultury symbolizowanej przez Schopenhauera, Nietzschego i Wagnera. Niemieccy pisarze uważali, że konsekwencje traktatu wersalskiego są krzywdzące dla narodu niemieckiego. Jeszcze w 1930 roku Mann oceniał, że rozbrojenie Niemiec było niesprawiedliwością ${ }^{31}$. Sytuacja zmieniła się jednak zupełnie w kolejnych latach Republiki Weimarskiej. Wtedy pisarze, weterani I wojny światowej, podjęli totalną krytykę służby wojskowej. Jednym z nich był Arnold Zweig, który w słynnej książce z 1927 roku Spór o sierżanta Griszę dowodził, że tyrania militarna jest największą tyranią ze wszystkich wówczas istniejących. W armii panują nieludzkie stosunki, struktura wojska ma charakter feudalny, a przypodobanie się zwierzchnikowi jest głównym celem podwładnego ${ }^{32}$. Relacje w wojsku reguluje wyłącznie strach $^{33}$. Wzorem więc stawali się nie tylko dezerterzy, ale także dekownicy - zwykli żołnierze, którzy zrobią wszystko, aby tylko nie wyjechać na front. Wrogami szeregowców nie były obce armie, ale przełożeni, dowództwo. To im w listopadzie 1918 roku okazywano pogardę, nie oddając honorów ${ }^{34}$. Żołnierze tworzący solidarną wspólnotę byli w opozycji wobec oficerów, a przede wszystkim generalicji. Dowodzono, że są to ludzie niewrażliwi, mało inteligentni, a także pełni kompleksów. Jednocześnie próżna generalicja stale oczekiwała pochlebstw ${ }^{35}$. Popularność antymilitaryzmu i zbliżenie do pacyfizmu w Niemczech po 1918 roku związane było z tym, że byli żołnierze poczuli się oszukani. Weterani uświadomili sobie, że wpajane w armii tzw. wojenne uniesienie było dobrze wymyślonym oszustwem. Dlatego Ernst Glaeser, słowami literackiego bohatera Kiliana Kerna, przestrzegał, że nie wolno po raz drugi dać się zmanipulować, tym bardziej że uważnie obserwujący niemiecką rzeczywistość pisarz dostrzegł, że Niemcom nie należy ufać w zapewnienia zachowania pokoju ${ }^{36}$. To właśnie weterani wojenni, nie tylko w Niemczech, ale i we Francji, Anglii, Belgii, stanowili podporę antywojennych ruchów i organizacji. Okaleczeni psychicznie i fizycznie weterani I wojny światowej na ulicach Londynu, Paryża, Wiednia czy Berlina zniechęcali młodych ludzi do służby wojskowej o wiele skuteczniej niż setki publikowanych pacyfistycznych pism i antymilitarystycznych ulotek.

${ }^{31}$ T. Mann, Moje czasy, wybór i wstęp H. Orłows ki, tłum. W. Kunicki, Poznań 2002, s. 235.

32 A. Zweig, Spór o sierżanta Griszę, tłum. W. Kragen, Warszawa 1997, s. 170-171.

33 Idem, Wychowanie pod Verdun, thum. W. Krage n, Warszawa 1977, s. 139.

${ }^{34}$ E. Glaeser, Pokój, thum. M. Was sermanówna, Warszawa 1933, s. 37.

${ }_{35}$ R. Musil, Człowiek bez właściwości, t. 2, tłum. K. Radziwiłł, K. Tuchanowski, J. Zeltzer, Warszawa 2002, s. 362.

${ }^{36}$ E. Glaeser, Ostatni cywil, thum. P. Hulka-La skowski, Warszawa 1938, s. 188, 200. 
W Republice Weimarskiej służba wojskowa nie była obowiązkowa. Zgłaszających się do Reichswehry ochotników poddawano starannej wieloetapowej weryfikacji. Armia Republiki Weimarskiej dawała szansę awansu społecznego. Szeregowcy i podoficerowie z wykształceniem podstawowym stanowili w pierwszej połowie lat 30. aż 84\% żołnierzy. Bardzo ważnym elementem była tężyzna fizyczna - przed związaniem się z Reichswehrą aż 35\% kandydatów należało do klubów sportowych i stowarzyszeń gimnastycznych ${ }^{37}$. Wszyscy, którzy deklarowali antymilitaryzm, w latach 1918-1935 nie musieli zakładać wojskowego munduru i nosić broni. Tylko pozornie Republika Weimarska wydawała się rajem dla pacyfistów. 12 marca 1929 roku w czasopiśmie „Die Bühne” ukazał się artykuł Windiges aus der deutschen Luftfahrt („Lustracja niemieckiego lotnictwa”). Jego autorem był Walter Kreiser, dziennikarz „Die Bühne” i ekspert lotniczy, który opublikował tekst pod pseudonimem Heinz Jäger. Przypomniał niemieckiemu społeczeństwu znany fakt, że Niemcy przy pomocy Armii Czerwonej odbudowują siły lotnicze. Nie ujawnił żadnej tajemnicy, czerpał z ogólnodostępnego protokołu 312 posiedzenia komisji budżetowej. Mimo tego zarówno on, jak i Carl von Ossietzky, redaktor naczelny „Die Bühne”, pacyfista, stanęli przed sądem. Wydawało się, że mimo poważnych oskarżeń o zdradę i szpiegostwo sprawa zakończy się pomyślnie. Znany z wrogości do pacyfistów prokurator Paul Jorns nie potraktował jednak oskarżonych pobłażliwie. 19 listopada 1931 roku von Ossietzky i Kreiser zostali skazani na 18 miesięcy więzienia ${ }^{38}$ za zdradę tajemnicy wojskowej. Jeszcze większą wrogość do instytucji wojska głosili w Niemczech w latach 1918-1933 dziennikarz Kurt Tucholsky i anarchistyczny aktywista Ernst Friedrich.

Pierwszy jest autorem słynnego sformułowania Soldaten sind Mörder - „żołnierze są mordercami”. Tucholsky od 1912 roku stale wypowiadał się publicznie, twierdząc, że wojny to ciągłe morderstwo, w którym role zabójców odgrywają profesjonalni mordercy nazywani żołnierzami. Takie sformułowania nie były nowe, wystarczy wspomnieć poglądy nieżyjącego już wówczas Tołstoja, jednak przysporzyły mu wielu wrogów, przy czym podczas I wojny światowej, jak i przez długie lata w Republice Weimarskiej, nic mu za nie nie groziło. W licznych publikacjach określał żołnierzy jako przestępców w mundurach, oficerów nazywał rzeźnikami. Przełomem był jego artykuł w 31. numerze „Die Bühne”, który ukazał się 4 sierpnia 1931 roku. Tucholsky zakończył go puentą: „Żołnierze są mordercami” ${ }^{39}$. Wtedy sprawą zainteresował się minister obrony Wilhelm Groener; Tucholsky przebywał już wówczas w Szwecji. Sformułowanie Soldaten sind Mörder weszło do niemieckiej debaty prawnej i publicznej.

Podobną pogardę dla wojska demonstrował niemiecki anarchosyndykalista Ernst Friedrich, który za bojkot służby wojskowej w 1914 roku trafił do szpitala psychiatrycznego. W 1916 roku brał udział w antywojennych demonstracjach młodzieży,

${ }^{37}$ W. Kozaczuk, Wehrmacht, Warszawa 2004, s. 24-25.

${ }^{38}$ Der Weltbühnen-Prozess um Carl von Ossietzky, „exilOgraph. Mitteilungen des P. Walter JacobArchivs der Walter-A.-Berendsohn-Forschungsstelle für deutsche Exilliterat” 2009, nr 17, s. 2.

39 „Soldaten sind Mörder”. Dokumentation einer Debatte 1931-1996, red. M. Hepp, V. Otto, Berlin 1996, s. 14-15 (cyt. w art. - tłum. R.K.). 
w latach 1924-1926 wydał dwutomową książkę pod tytułem Krieg dem Kriege („Wojna przeciwko wojnie”). Twierdził w niej, że system oświatowy, nauczanie Kościoła i militarne zabawki od wczesnych lat psychicznie przygotowują dzieci do walki. W 1925 roku założył w Berlinie muzeum antywojenne. W 1930 roku został aresztowany i skazany na rok więzienia za „zdradę stanu”. Rzeczywistym powodem był jednak druk pism adresowanych do wojska i policji, a także zamiar ich dystrybucji w tych środowiskach ${ }^{40}$. Erich von Manstein wspominał, że w Republice Weimarskiej Reichswehra była traktowana z pogardą. Komuniści określali tę armię mianem „knechty kapitalizmu”, inni nazywali ją najemnikami. Nie cieszyła się ona zaufaniem $^{41}$. Obraz stworzony przez von Mansteina pokazuje, że Reichswehra była siłami zbrojnymi funkcjonującymi w niemal powszechnie wrogim otoczeniu. To jednak zupełnie subiektywny obraz. Wśród licznych niemieckich instytucji państwowych w latach 1919-1933 panowała tymczasem wręcz apoteoza armii. Wielu generałów niemieckich oburzało się zaś, że w tym czasie do armii wprowadzono ograniczenia poboru. Mimo pozorów antymilitaryzmu w Republice Weimarskiej strzeżono pruskiej tradycji armii ${ }^{42}$. Warto pamiętać, że duża część niemieckiego społeczeństwa czuła upokorzenie po I wojnie światowej. Dla środowisk, które uważały, że Niemcy w listopadzie 1918 roku zostały przez międzynarodową społeczność skrzywdzone licznymi postanowieniami, istnienie tej niewielkiej, oficjalnej, ale własnej armii było formą minimalnego zadośćuczynienia.

W ciągu trzynastu lat istnienia Republiki Weimarskiej funkcjonowało blisko 40 partii, z których znaczna część miała różnego rodzaju związki z niemieckim pacyfizmem. Przez blisko dekadę największym poparciem cieszyła się umiarkowana frakcja DFG, którą popierali socjaliści z Sozialdemokratische Partei Deutschlands, czyli SPD (Socjaldemokratycznej Partii Niemiec), katolicy z Deutsche Zentrumspartei (Niemieckiej Partii Centrum), a także liberałowie z Deutsche Demokratische Partei (DDP; Niemieckiej Partii Demokratycznej). W połowie lat 20. do DFG należało aż 44\% członków SPD, 26\% DDP, 5\% zaś do Deutsche Zentrumspartei. Katolicy z Niemieckiej Partii Centrum, a także innych mniejszych partii odwołujących się do chrześcijańskich wartości popierali głównie FDK. Od początku lat 20. znaczny wpływ na niemiecki pacyfizm posiadała także Kommunistische Partei Deutschlands (KPD), to jest Komunistyczna Partia Niemiec. Komuniści najpierw podporządkowali sobie antymilitarystyczny BNV, a potem DLfM, która powstała wskutek przekształcenia się BNV. Od lata 1932 roku KPD przejęła faktyczne dowodzenie nad całym ruchem pacyfistycznym w Niem$\operatorname{czech}^{43}$. Jak pokazała niedaleka przyszłość, był to połowiczny sukces komunistów.

Nie sposób ukazać wszystkich ugrupowań politycznych w weimarskich Niemczech, które wysuwały w swoich programach postulat pokoju. Należy jednak wspomnieć o Deutschen Liga für Völkerbund - (DLfV; Niemieckiej Sekcji Stowarzyszeń

${ }^{40}$ D. Kellner, Ernst Friedrich's Pacifistic Anarchism, http://www.gseis.ucla.edu/faculty/kellner/ kellner.html., [dostęp: 25 I 2016 r.] (cyt. w art. - tłum. R.K.).

${ }^{41}$ E. von Manstein, Żolnierskie życie. Moja stużba w Reichswehrze i Wehrmachcie 1919-1939, Kraków 2013, s. 126.

${ }^{42}$ T. Kotłow sk i, Historia Republiki Weimarskiej (1919-1933), Poznań 1997, s. 227.

${ }^{43}$ K. Fiedor, Niemiecki ruch ..., s. 109-113, 122-123, 137-142, 253-256. 
Ligi Narodów). DLfV na pacyfistycznej mapie Niemiec stanowiła pewne kuriozum; od 1925 roku w jej szeregach działali przedstawiciele prawicowej Deutsche Volkspartei (DVP; Niemieckiej Partii Ludowej), latem 1926 roku zaś do jej zarządu trafiły osoby należące do Deutschnationale Volkspartei (DNVP), czyli partii narodowo-konserwatywnej, nastawionej wrogo do konstytucji weimarskiej, jawnie opowiadającej się za powrotem obowiązkowej służby wojskowej ${ }^{44}$. Wśród blisko czterdziestu partii, które funkcjonowały w czasach Republiki Weimarskiej, istniała jedna, która do pacyfizmu, nie wspominając o antymilitaryzmie, miała wyjątkowo negatywne nastawienie. Nationalsozialistische Deutsche Arbeiterpartei (NSDAP; Narodowosocjalistyczna Niemiecka Partia Robotników) od lutego 1920 roku, czyli od chwili swojego powstania, zakładała wprowadzenie powszechnej i obowiązkowej służby wojskowej oraz powstanie silnej armii narodowej.

Narodowi socjaliści na długo przed zdobyciem władzy w kraju nie mieli wątpliwości, że pacyfizm najchętniej rozpowszechniają Żydzi w celu rozkładu morale i ogłupienia narodu niemieckiego. Hitler określał pacyfizm jako absurd „wrogi ludzkiej naturze i rozsądkowi”, któremu ufają jedynie „fantaści”. W Mein Kampf cynicznie twierdził, że „faktycznie idea pacyfistyczna, godna człowieka, jest być może całkiem dobra wtedy, gdy najwyżej stojący człowiek przedtem zdobędzie i podporządkuje sobie świat w takim zakresie, który uczyni z niego jedynowładcę tej ziemi” ${ }^{\prime 4}$. Po upływie dziesięciu lat od napisania tych słów ich autor zaczął je w pełni realizować.

Upadek niemieckiego ruchu pacyfistycznego nastąpił z chwilą objęcia władzy przez Hitlera. W III Rzeszy nie tylko zlikwidowano organizacje, ale ze szczególną zawziętością ścigano osoby krytykujące służbę wojskową i nawołujące do jej bojkotu. Przeciwnicy militaryzacji wyjeżdżali lub uciekali za granicę, tych, którzy pozostali w kraju, represjonowano. Po 1933 roku tylko nieliczne osoby podejmowały w Niemczech działania antymilitarystyczne. Był wśród nich Hermann Stöhr, który w sierpniu 1939 roku - po dwukrotnej odmowie służby wojskowej - został aresztowany ${ }^{46}$. W czerwcu 1940 roku wykonano na nim wyrok śmierci. Likwidacja pacyfizmu w Niemczech oznaczała również kres zbliżenia z Francją, o co usilnie zabiegała dotąd znaczna część pacyfistów w tych krajach.

\section{FRANCJA}

W 1920 roku po odbyciu długoletniej kary więzienia na wolność wyszedł znany antymilitarysta Louis Lecoin. Jednak znacznie większego rozgłosu nabrała we

44 Ibidem, s. 192-195.

${ }^{45}$ A. Hitler, Mein Kampf. Moja Walka. Edycja krytyczna, z języka niemieckiego przełożył, wstępem, przypisami i bibliografią selektywną opatrzył E.C. Król, Warszawa 2020, s. 331.

${ }^{46}$ (p m), Wystawa Hermann Stöhr - Stanisław Kubicki. Zginęli w tej samej sprawie, Szczecin, X 2016 r., s. 1. 
Francji w 1923 roku tzw. sprawa Rosera. Ten francuski oficer służył na froncie I wojny światowej od kwietnia 1919 roku, a służbę wojskową zakończył w marcu 1921 roku jako porucznik rezerwy. Podjął studia teologiczne i został pastorem, promował radykalne antymilitarystyczne poglądy. Już wtedy francuskie władze z podejrzliwością obserwowały jego kaznodziejskie działania, w których negował sens służby wojskowej, całkowicie - jak głosił - niezgodny z przesłaniem Ewangelii. W styczniu 1923 roku, kiedy wojska francuskie zajęły Zagłębie Ruhry, Roser publicznie ogłosił się obdżektorem i w geście protestu odesłał dokumenty wojskowe. W jego przekonaniu była to forma sprzeciwu wobec rozprzestrzeniania się nieewangelicznego militaryzmu. W kolejnych latach, zwłaszcza od roku 1927 do 1928, Roser pozostawał niekwestionowanym liderem francuskiego ruchu pacyfistycznego. Od 1928 roku był sekretarzem we francuskiej sekcji International Fellowship of Reconciliation, czyli Misji na rzecz Pokoju ${ }^{47}$. Francuskim władzom radykalni pacyfiści nie byli obojętni, od czasu do czasu stosowały wobec nich różnego rodzaju szykany. Prześladowania we Francji, zdecydowanie poważniejsze niż w Wielkiej Brytanii, były zawsze złym sygnałem dla pacyfistów z innych krajów Europy. Wszelkie restrykcje śledzono z niepokojem. Nie inaczej było w Polsce. W 1935 roku odnotowano uwięzienie pastorów Verniera i Martina. Oskarżono ich o tzw. aktywny antymilitaryzm i po raz drugi ukarano ich więzieniem ${ }^{48}$. List protestacyjny do Pierre'a Lavala, ministra spraw zagranicznych Francji, skierowało w ich obronie między innymi duchowieństwo protestanckie i intelektualiści z Finlandii. We Francji karano nie tylko duchownych. W latach 1927-1928 na kilkumiesięczne więzienie skazano odmawiających służby wojskowej pacyfistów: Georges'a Chevè, Henri Abriala, Rogera Lipplera, Louisa Baucheta i Louisa Pragneta ${ }^{49}$. Znacznie częściej niż w innych państwach Europy sądzone były tam osoby duchowne oraz radyklani działacze protestanccy i katoliccy. Wszyscy, którzy publicznie potępiali służbę wojskową i odwoływali się przy tym do Biblii, byli źle przyjmowani zarówno przez konserwatywną prawicę, jak i zeświecczoną lewicę.

W zlaicyzowanej Francji znacznie większą swobodę działania miały organizacje liberalne i lewicowe. Jedną z najbardziej aktywnych w latach 1931-1939 była La Ligue internationale des combattants de la paix (LICP), czyli Międzynarodowa Liga Walczących o Pokój. Jej założycielem był Victor Célestin Méric, który powołał do życia również słynną pacyfistyczną gazetę „La Patrie Humaine”. Czołową rolę w Lidze odgrywali Camille Drevet, René Gérin, Georges Pioch, Marianne Rauze, Félicien Challaye. LICP wspierali także filozof Émile-Auguste Chartier i pisarz Jean Giono. Związani z Ligą pacyfiści nie opierali swojego ruchu na jakimkolwiek wyznaniu religijnym. Wielu z nich w pesymistycznych mowach głosiło, że rozpoczęta w XX wieku wojna zniszczy cywilizowane życie na naszej planecie. LICP wskazywała, że po zakończeniu wojny pozostaną tylko zwycięzcy. Związani z LICP aktywiści zdecydowanie sprzeciwiali się służbie wojskowej i atakowali bardziej zachowawczych

${ }^{47}$ Ch. Chala met, Revivalism and Social Christianity: The Prophetic Faith of Henri Nick and André Trocmé, Eugene 2013, s. 61, 77-78.

48 Kronika pacyfistyczna, „Wolnomyśliciel Polski” 1935, nr 47, s. 557.

${ }^{49}$ M. Devaldès, Sprzeciw sumienia, tłum. A. Kurlandzka, Warszawa 1930, s. 83-84. 
pacyfistów, którzy dopuszczali możliwość wojny defensywnej. Posunięcia LICP z pewnością nie podobały się wszystkim francuskim zwolennikom pacyfizmu, a nawet szeroko rozumianej lewicy. Victor Méric był także nieufny i wrogi wobec stalinowskiego Związku Sowieckiego, co jeszcze bardziej drażniło francuską lewicę. Jednak największe oburzenie Méric wywołał stwierdzeniem, że nie widzi żadnego zagrożenia pokoju ze strony Hitlera i Mussoliniego. Członków LICP podzieliła również kwestia odpowiedzialności za wojnę domową w Hiszpanii, jej przebieg i skutki. Od początku do końca ani siły walczące po stronie Republiki, ani też zwolennicy gen. Franco nie byli popierani przez tę organizację. W obrębie LICP panował dość wyraźny pluralizm światopoglądowy. Swoboda wypowiedzi i autonomia wystąpień świadczyły o demokratyzmie organizacji, czasem jednak ją także kompromitowały. Co gorsza, nietrafne analizy i wypowiedzi nie tylko fałszowały rzeczywistość, ale zwodziły opinię społeczną. Przykładem może tutaj być René Gérin, który we wrześniu 1938 roku uparcie twierdził, że zawarcie układu monachijskiego nie stanowiło kroku w stronę wojny ${ }^{50}$. Również we Francji w negowanie wartości służby wojskowej włączyło się liczne grono pisarzy. Co ciekawe, nie zawsze byli to obdżektorzy, lewicowi pacyfiści czy komunizujący antymilitaryści. W 1932 roku została opublikowana Podróż do kresu nocy Louisa-Ferdinanda Céline'a, pisarza, który po odwiedzeniu ZSRR wyzbył się jakichkolwiek lewicowych złudzeń. Autobiograficzna powieść nie tylko ukazała brutalność wojny i szaleństwo dowodzących. Céline ujął się w książce także za wszystkimi, którzy odmówili przelania krwi w obronie ojczyzny. W słowach pełnych emocji nazywał głoszenie haseł patriotycznych manipulacją ze strony rządzących ${ }^{51}$. Twórczość i antysemickie poglądy Céline'a wywoływały we Francji liczne kontrowersje. Warto wspomnieć, że podobną ewolucję poglądów przeszedł Marcel Déat. Rozczarowany socjalizmem i pacyfizmem z czasem stał się faszystą, a w czasie II wojny światowej czynnie kolaborował z Niemcami.

$Z$ francuskim pacyfizmem i antymilitaryzmem przed wybuchem II wojny światowej sympatyzowali kombatanci, chłopi, ale przede wszystkim inteligencja, szczególnie dziennikarze, pisarze i nauczyciele. W opinii Maurice Vaïsse to Syndicat National des Instituteurs (SNI; Związek Narodowy Nauczycieli) od 1930 roku był fundamentem francuskiego pacyfizmu. SNI wchodził w skład Powszechnej Konfederacji Pracy (Confédération générale du travail; CGT), politycznie związanej z francuską partią komunistyczną. W 1937 roku SNI zrzeszał 100000 nauczycieli, większość z nich uczyła w szkołach podstawowych. W 1939 roku SNI stanowił 10\% wszystkich członków CGT. Od 1929 roku SNI wydawał periodyk „L’Ecole Libératrice”. Od 1932 roku na jego łamach, a także we wszystkich szkołach, w których pracowali nauczyciele należący do SNI, głoszono skrajne poglądy pacyfistyczne, uczestniczono w antymilitarystycznych kampaniach, wzywano do oporu przeciwko rozbudowie i umacnianiu sił zbrojnych. Poza „L'Ecole Libératrice” wydawano także „Le Peuple”, ale SNI do propagowania antymilitaryzmu wykorzystywał nie tylko sale lekcyjne i publicystykę. Ulubioną formą manifestowania niechęci do instytucji

\footnotetext{
50 P. Brock, N. Young, Pacifism..., s. 97-98.

51 L.-F. Céline, Podróż do kresu nocy, tłum. O. Ha de man, Izabelin 2005, s. 77.
} 
wojska i potępienia wojny wśród nauczycieli ze SNI były spotkania przy nowo powstających pomnikach, upamiętniających poległych w I wojnie światowej ${ }^{52}$. Takie działania nie pozostawały obojętne dla woli walki i szacunku dla służby wojskowej francuskiej młodzieży. Poza pisarzami, dziennikarzami i nauczycielami aktywni byli także pracownicy francuskiej poczty i czołowi działacze lewicowych związków zawodowych. To wśród tej grupy zawodowo-społecznej tuż przed układem monachijskim w 1938 roku rozpoczęto akcję pod hasłem: „Nie chcemy wojny”. Bardzo szybko zebrano 150000 podpisów, notabene, aż 57\% Francuzów z wielkim entuzjazmem przyjęło decyzje podjęte $\mathrm{w}$ Monachium ${ }^{53}$. Jeszcze raz należy przypomnieć, że w rozbudzonej niechęci do służby wojskowej we Francji dużą rolę odgrywała trauma I wojny światowej. Obojętność wobec wojska była zauważalna już w latach 20. Polska ambasada w Paryżu jesienią 1924 roku informowała MSZ w Polsce, że sprawy wojskowe w rzeczywistości niewiele interesują francuską opinię publicz$\mathrm{ną}^{54}$. Zaangażowanie w ruch pacyfistyczny takich autorytetów jak Romain Rolland, francuski noblista z 1915 roku, z pewnością przekonało wahających się. Zdaniem Gilberta Merlio już od początku lat 30. francuskie społeczeństwo było w większości pacyfistyczne ${ }^{55}$. Taki „duch narodu” nie sprzyjał społecznej akceptacji dla wojska. Przyniosło to fatalne skutki w 1940 roku.

Od lipca do września 1940 roku Marc Bloch pisał Dziwna klęskę, w której rozliczył Francję z porażki, stwierdzając, że geneza defetystycznych postaw z czerwca 1940 roku tkwiła w hekatombie wielkiej wojny - Francuzi woleli zgodzić się na „wszystko inne”, aby tylko nie powróciły minione wydarzenia. Bloch uznał, że w latach 1918-1939 we francuskim społeczeństwie zwolnienie ze służby wojskowej traktowano jako przywilej, a nawet obywatelskie prawo, co nie wykształciło więzi wojska i narodu ${ }^{56}$. Potępił również rodzimych pacyfistów, porównując ich do fałszywych apostołów głoszących na „pozór wygodną ewangelię”. W jego przekonaniu pacyfistyczna „dobra nowina” zwiodła bezmyślnie wielu „uczniów” potępieniem każdej wojny, twierdzeniem, że konflikty zbrojne są jedynie problemem ludzi zamożnych i liderów politycznych ${ }^{57}$.

Od drugiej połowy lat 20. idee pacyfistyczne oddziaływały w różnej skali na prawie wszystkie kolejne rządy międzywojennej Francji. Przełomowymi momentami dla francuskiej polityki było podpisanie 16 października 1925 roku traktatów w Locarno, a 27 sierpnia 1928 roku paktu Brianda i Kellogga. Norman Ingram to ostatnie porozumienie określił jako punkt kulminacyjny francuskiego pacyfizmu. Pakt z 1928 roku utwierdził bowiem sporą część francuskich polityków w przekonaniu,

${ }^{52}$ M. Vaïsse, Der Pazifismus und die Sicherheit Frankreichs 1930-1939, „Vierteljahrshefte für Zeitgeschichte" 1985, z. 4, s. 601.

${ }_{53}$ G. Merlio, Le pacifisme en Allemagne et en France entre les deux guerres mondiales [w:] Le pacifisme en Allemagne Du Reich wilhelmien à la fin de la République de Weimar (1890-1933), red. A D upeyrix, „Revue Les cahiers Irice” 2011, nr 8, t. 2, s. 56-57 (cyt. w art. - thum. R.K.).

${ }^{54}$ AAN, Ambasada Polska w Paryżu, pismo z 8 października 1924 r, sygn. 72, k. 30.

${ }_{55}$ G. Merlio, op. cit., s. 56.

${ }_{56}^{5}$ M. Bloch, Dziwna klęska, tłum. K. Marczewska, Warszawa 2008, s. 214.

${ }^{57}$ Ibidem, s. 224-225. 
że międzynarodowy porządek, który powstał w Wersalu, zmierza we właściwym kierunku $^{58}$. Jeszcze większy wzrost zaufania do pacyfizmu miał miejsce we Francji od początku lat 30., o czym pisałem już wcześniej. Niezwykle trafnie oddał ten nastrój wspomniany już wcześniej Vaïsse, na co zwróciła uwagę w artykule Małgorzata Gmurczyk-Wrońska. Vaïsse stwierdził, że „,...] pacyfizm francuski w latach 30. był częścią życia społecznego, wojskowego i politycznego Francji. Było to nie tylko dążenie do zachowania pokoju, nawet za wszelką cenę, ale także wiązało się z planami reform, symbolizowało wartości moralne, religijne, stawało się wręcz synonimem patriotyzmu. Pacyfizm był bardzo silny w środowiskach socjalistów, komunistów, radykałów, chrześcijańskich demokratów, kombatantów"59. Jak się okazało, niemal powszechne we Francji lat 30. zaufanie do pacyfizmu czy bezkrytyczne traktowanie pokojowych porozumień nie zagwarantowało stabilnej przyszłości.

\section{WSPÓŁPRACA I KONTAKTY EUROPEJSKICH PACYFISTÓW}

Trauma I wojny światowej przewartościowała również poglądy wielu wysokich rangą wojskowych z Francji i Niemiec. Niedawni wojownicy oraz wrogowie zmieniali się w radykalnych pacyfistów i przyjaciół. Jesienią 1926 roku jeszcze niewiele wcześniej aktywni zawodowo niemieccy generałowie Berthold von Deimling, Paul Freiherr von Schoenaich i francuski gen. Martial Justin Verraux, a także oficerowie z okresu I wojny światowej Franz Carl Anders (autor pacyfistycznej książki Die Tragödie Deutschland), Harry Graf Kessler oraz sześćdziesięciu innych przeciwników wojny z całego świata (wśród nich Mahatma Gandhi) podpisało Międzynarodowy manifest przeciwko obowiazkowej stużbie wojskowej. W wysłanym do Ligi Narodów dokumencie podkreślono, że zniesienie obowiązkowego poboru do wojska jest pierwszym krokiem do prawdziwego rozbrojenia ${ }^{60}$. Nawet ci byli generałowie, którzy nie podzielali tak radykalnego antymilitaryzmu, ale pamiętali okrucieństwa wojny, sugerowali zwalczanie niebezpiecznego mitu tzw. romantycznej wojny. Wśród nich był angielski gen. Ian Hamilton, od 1928 roku przewodniczący stowarzyszenia niemiecko-brytyjskiego, którego celem było pojednanie między dwoma narodami. Ogromne wrażenie zrobiła na nim książka Na Zachodzie bez zmian. W liście z 19 czerwca 1929 roku do Remarque'a Hamilton pisał: „Wielka i straszliwa jest bowiem potęga romantyzmu i piękna wojny, którą zapobiegliwie Pan w swojej książce pomija”. Zachęcał niemieckiego pisarza do napisania kolejnej książki. Remarque miałby w niej jeszcze mocniej piętnować zafałszowany obraz

${ }^{58}$ N. Ingram, The Politics of Dissent: Pacifism in France, 1919-1939, (wersja pracy doktorskiej), University of Edinburgh, Edinburg 1988, s. 52, https://era.ed.ac.uk/handle/1842/6876 [dostęp: $18 \mathrm{~V}$ 2021 r.].

${ }^{59}$ M. Gmurczyk-Wrońska, Rok 1939 w historiografii francuskiej, „Dzieje Najnowsze” 2009, nr 3, t. XLI, s. 118.

${ }^{60}$ K. Zirke1, op. cit., s. 389. 
wojny, w której nie ma ofiar, a dzielni i nieśmiertelni żołnierze toczą urzekające boje z wrogiem. Hamilton pisał: „To są legendy i iluzje, które Pan musi jak najszybciej przebić swoim piórem" ${ }^{61}$. Międzynarodowy manifest przeciwko obowiazkowej stużbie wojskowej był kulminacyjnym punktem antywojskowych nastrojów w Europie Zachodniej. To właśnie w Holandii w styczniu 1923 roku i lutym 1925 roku odbyły się międzynarodowe spotkania przeciwko służbie wojskowej. Pierwsze miało miejsce w Bilthoven, a drugie - w Hoddesolon. Wybór Bilthoven nie był przypadkowy. To właśnie w tym mieście w 1921 roku powstała organizacja War Resisters' International (WRI) - Międzynarodowe Stowarzyszenie Przeciwników Wojny. Większy rozgłos zyskało jednak spotkanie w lutym 1925 roku w Hoddesolon. Przedstawiciele różnych krajów ogłosili manifest potępiający szkolenie wojskowe, zażądali również zniesienia służby wojskowej. W dokumencie stwierdzono, że pobyt młodych ludzi w koszarach, wpajanie im ślepego posłuszeństwa i bezmyślnego wykonywania rozkazów niszczy ludzką osobowość. Oświadczono, że system szkolenia rekrutów jest ogłupiającą tresurą, która prowadzi nie tylko do poniżenia, lecz również odbiera ludziom ich fundamentalne wolności ${ }^{62}$. Warto dodać, że w holenderskich spotkaniach nie wzięli udziału przedstawiciele z Polski.

Toczące się w latach 30 . konflikty zbrojne coraz bardziej niepokoiły. Wśród przeciwników militaryzmu nie brakowało radykalnych pomysłów, aby natychmiast je przerwać. W 1932 roku pastor Maude Royden z Londynu wraz z grupą osób tworzących Armię Pokoju wystosowała dramatyczny list do Ligi Narodów. Piszący oświadczyli w nim, że chcą wyruszyć na Daleki Wschód, aby zmusić walczących Chińczyków i Japończyków do zawarcia pokoju. Planowali utworzyć ze swoich ciał mur oddzielający japońskich i chińskich żołnierzy - po przybyciu na linię frontu zamierzali bez broni stanąć pomiędzy walczącymi stronami ${ }^{63}$. Od lutego 1932 roku w wielu miastach Europy Zachodniej organizowano również marsze pokojowe.

Nie miało to większego znaczenia, a sytuacja na świecie stawała się coraz bardziej niebezpieczna. Nie tylko na Dalekim Wschodzie, także w Europie - w 1935 roku doszło do agresji Włoch na Abisynię, w 1936 wybuchła wojna domowa w Hiszpanii. To ostatnie wydarzenie podzieliło na świecie szeroko rozumiane lewicowe kręgi pacyfistyczno-antymilitarystyczne, które zastanawiały się, czy czynny udział $\mathrm{w}$ tej wojnie będzie zgodny z założeniami pacyfizmu. Hiszpańscy antymilitaryści przeżywali dylematy co do stosowania przemocy na długo przed wybuchem wojny domowej. Z jednej strony powstała $\mathrm{z}$ hiszpańskiej frakcji WRI i związków zawodowych w 1932 roku inicjatywa „Orden den Olivo” odrzucała militarną przemoc jako sposób rozwiązywania problemów, a także negatywnie odnosiła się do instytucji armii. Wielu hiszpańskim libertarianom bliskie były również pokojowe wypowiedzi antyfaszystowskiej działaczki Amparo Poch y Gascón. Z drugiej strony większość

${ }^{61}$ E.M. Remarque. Wojujący pacyfista. Artykuly i wywiady 1929-1966, wybór i wstęp T.F. Schneider, thum. W. Kunicki, Warszawa 1998, s. 48.

${ }^{62}$ K. Fiedor, Ruch pacyfistyczny. Studia nad geneza i formami dziatania do 1939 roku, „Dzieje Najnowsze" 1980, nr 2, t. 12, s. 65.

${ }^{63}$ A.T. Nilsson, ABC ruchu na rzecz pokoju. Daty i fakty, słowo wstępne T. Kotarbiński, Z. Nałkowska, Warszawa 1937, s. 37. 
silnych ruchów anarchistyczno-syndykalistycznych skupionych w Federación Anarquista Ibérica (Iberyjskiej Federacji Anarchistycznej), jak również w Confederación Nacional del Trabajo (Krajowej Konfederacji Pracy), choć odnoszących się z pewną sympatią do antymilitaryzmu, ostatecznie nigdy nie odżegnywało się od podjęcia walki. Taka tendencja przeważyła również w hiszpańskim ruchu pacyfistycznym. José Brocca Ramón, jeden z liderów hiszpańskiego pacyfistycznego ruchu, w liście skierowanym na początku wojny do Herberta Runham Browna, sekretarza WRI, stwierdził: „W okolicznościach, w których nastąpiło faszystowskie powstanie, ludzie nie mieli innej możliwości niż stawianie czoła przemocy z użyciem przemocy" ${ }^{\prime}$. Wojna domowa w Hiszpanii wykazała, jak szybko nawet najzagorzalsi pacyfiści zostali zwolennikami walki.

$\mathrm{Na}$ początku lat 30. przeciwnicy militaryzmu dalej mieli nadzieję, że pozytywną zmianę przyniosą europejskie kongresy pacyfistyczne organizowane w różnych krajach. Do najważniejszych należał Międzynarodowy Kongres Przeciwko Wojnie, który odbył się w Amsterdamie w dniach 27-29 sierpnia 1932 roku. Zjawiły się na nim delegacje z 29 krajów, w tym z Francji, Polski, Niemiec, Włoch, Czechosłowacji, Holandii, Wielkiej Brytanii, Austrii, Danii, Norwegii, Stanów Zjednoczonych, Chin, Japonii, Indonezji, a także państw Ameryki Południowej. Zebrani na kongresie wezwali wszystkie społeczeństwa na świecie do jedności działania w obronie pokoju i demokracji ${ }^{65}$. Duże kongresy pacyfistyczne odbyły się także, o czym już pisałem, w 1924 roku w Berlinie oraz w Warszawie w czerwcu 1928 roku $^{66}$.

Wielkie kongresy pokojowe, choć wiązano z nimi ogromne nadzieje, często obnażały niespójność ideową pacyfizmu. Pokazały to też przygotowania do kongresu pokojowego w Brukseli, zaplanowanego na 4-6 września 1936 roku. Komunistyczni organizatorzy już przed jego rozpoczęciem oskarżyli integralnych pacyfistów i tzw. lewych (czyli niebędących komunistami) sekciarzy o dezintegrację ruchu pacyfistycznego. Uważano, że religijni pacyfiści poprzez odwoływanie się do tołstojowskiej nauki o „niesprzeciwianiu się złu złem” sprzyjają rozwojowi faszyzmu. „Lewi sekciarze" mieli natomiast lekceważyć potęgę „ludu pracującego" państw kapitalistycznych. Organizatorzy zarzucili im również fatalistyczne wieszczenie nieuchronności wybuchu wojny ${ }^{67}$. Kongres ten pokazał, jak trudno jest zbudować jednolite stanowisko w obronie pokoju.

Nieprzerwane i szczere zaangażowanie tysięcy osób o różnych światopoglądach społeczno-politycznych w ruchy oraz organizacje pacyfistyczne i antymilitarystyczne w wielu krajach w dwudziestoleciu międzywojennym miało jeszcze jedno źródło. Wszyscy, którzy duże nadzieje na umocnienie pokoju na świecie wiązali z powstałą

${ }^{64} \mathrm{~F}$. Mendiola, Cogs in the military machine? War experience and antimilitarism during the Spanish Civil War, ,Workers of the World: International Journal on Strikes and Social Conflict” 2016, t. I, nr 6, s. 11 (cyt. w art. - thum. R.K.).

${ }_{65}$ J. Ślu sarczyk, Idea pokoju w europejskiej i polskiej myśli politycznej do 1939 roku, Warszawa 1995, s. 83-84.

${ }^{66}$ (PAT), Międzynarodowy kongres pacyfistów w Warszawie, „Goniec Śląski” 1928, nr 146, s. 1.

${ }^{67}$ Światowy Kongres Pokoju w Brukseli. Nakładem Komitetu Obrony Pokoju przy Lidze Obrony Praw Człowieka i Obywatela, Oddział w Sosnowcu, 1936, s. 6. 
10 stycznia 1920 roku Ligą Narodów, mogli czuć się rozczarowani jej zupełną niemocą w podejmowaniu praktycznych działań w obronie zagrożonego pokoju i eskalacji militaryzmu. Jedną z przyczyn był słynny 8 . artykuł Paktu Ligii, który pozwalał na subiektywną ocenę rozbrojenia. Na podstawie tego artykułu każde z państw członkowskich Ligi mogło uznać, że rozbrojenie w ich kraju zagraża jego bezpieczeństwu. Brak wiary w powszechne i pełne rozbrojenie podzielali również współtwórcy systemu wersalskiego, między innymi George Clemenceau. Nie wierzono też w realizację traktatów pokojowych, które zostały narzucone państwom pokonanym. Jak zauważył analizujący historię Ligi Narodów Stanisław Sierpowski, programy rozbrojeniowe traktowano nieprzychylnie w większości państw w Europie, szczególnie tych nowo powstałych. Odrodzone armie w Polsce czy Finlandii symbolizowały wręcz niepodległość. Niektóre kraje należące do Ligii Narodów, jak wymienione Polska i Finlandia, a także Rumunia, od początku niechętne były redukcji armii i ograniczeniom zbrojeń, argumentując to zagrożeniem ze strony bolszewickiej Rosji ${ }^{68}$. Doświadczenia Polski z 1920 roku uzasadniały takie stanowisko.

Kolejne lata funkcjonowania Ligi Narodów jedynie upewniały radyklanych pacyfistów i antymilitarystów, że organizacja ta nie zatrzyma wybuchu żadnej wojny. Czarę goryczy przelał włoski podbój Abisynii zaakceptowany przez Wielką Brytanię i Francję w listopadzie 1938 roku $^{69}$. Spośród ważniejszych krajów europejskich podboju Etiopii nie zaaprobował jedynie należący od 1934 roku do Ligii Narodów Związek Sowiecki. Nic dziwnego, że w dalekich od Moskwy Paryżu i Londynie, zaniepokojonych kruchym pokojem i niekoniecznie sympatyzujących z komunizmem, uznano, że właśnie ZSRR może być gwarantem pokoju.

W międzywojniu urzeczywistnienie trwałego pokoju w Europie widziano także w zjednoczeniu kontynentu. Była to idea Paneuropy. Jej twórca Richard Coudenhove-Kalergi główne zagrożenie dla stabilizacji Europy upatrywał w napięciach lokalnych i różnych konfliktach zbrojnych, których nie zakończyła I wojna światowa. Coudenhove-Kalergi swoją koncepcją integracji europejskiej zainteresował różne partie polityczne, stowarzyszenia i organizacje, a także polityków oraz intelektualistów. Na przełomie lat 20. i 30. ruch paneuropejski mocno popierali Aristide Briand, Éduard Daladier, Gustav Stresemann, Albert Einstein czy Stefan Zweig, a więc osoby, którym idee pacyfizmu, a nawet radykalniejszego antymilitaryzmu były bardzo bliskie. Coudenhove-Kalergi wykładnię swoich poglądów wyraził w opublikowanej w 1923 roku książce Paneuropa. Przestrzegał, że niezintegrowana Europa stanie się źródłem międzynarodowych wojen, a także problemów, których - jak oceniał - nie jest w stanie rozwiązać istniejąca Liga Narodów. Dość krytyczny pozostawał również jego stosunek do funkcjonujących ruchów pacyfistycznych. Jak pisał Marian Leczyk: „Coudenhove-Kalergi - optymista i wizjoner - był pesymistą w odniesieniu do aktualnej rzeczywistości europejskiej. Nie wierzył w skuteczność traktatów pokojowych, którymi spacyfikowano powojenną Europę, nie wierzył w skuteczność ruchów

${ }^{68}$ S. Sierpow ski, Liga Narodów w latach 1919-1926, Wrocław-Warszawa-Kraków 2005, s. 247 250 .

${ }^{69}$ W. B alc erak, Liga Nadziei. Z dziejów Ligi Narodów, Warszawa 2010, s. 213. 
pacyfistycznych, wychodzących z idealistycznych przesłanek psychologicznych" "70. Prawdziwy i trwały pokój w powstałej nowej, wspólnej Europie zapewnić mieli nie pacyfiści, ale powołane do tego instytucje. Przed 1939 rokiem koncepcja Paneuropy nie została zrealizowana, tak jak pacyfiści i antymilitaryści nie zapewnili jej pokoju.

\section{„POŻYTECZNI IDIOCI”}

Brytyjski appeasement $\mathrm{i}$ francuska niemal religijna wiara w pacyfizm okazały się prawdziwym darem dla rodzącej się III Rzeszy. Hitler oraz jego zwolennicy szybko i doskonale zrozumieli, że lewicowi, a także prawicowi brytyjscy i francuscy politycy, wyczuwając nastroje swoich społeczeństw, uczynią wiele, aby w żaden sposób nie dopuścić do wybuchu nowej wojny. Nowy kanclerz nie miał złudzeń, że idee pacyfizmu, którymi gardził i które wyśmiewał w Mein Kampf, są niezwykle ważne dla Brytyjczyków i Francuzów. Jak pisał Alan Bullock: „Intuicyjnie wyczuwał pragnienia pokoju tych ludów, idealizm pacyfistów" "71. Hitler postanowił to wykorzystać. 17 maja 1933 roku wygłosił w Reichstagu słynną Friedensrede, czyli mowę pokojową, w której podkreślał swoją nienawiść do wojny, a także zapewniał, że Niemcy natychmiast rozwiążą organizacje militarne, zrezygnują z broni ofensywnych, podpiszą każdy pakt o nieagresji, jeśli tylko inne mocarstwa uczynią to samo ${ }^{72}$. Słowa te były adresowane przede wszystkim do Wielkiej Brytanii, Francji, a także Stanów Zjednoczonych.

15 października 1933 roku Niemcy wystąpiły z Ligii Narodów i ostatecznie opuściły Konferencję Rozbrojeniową, nie uzyskując prawa własnych zbrojeń przy równoczesnym rozbrojeniu się mocarstw zachodnich ${ }^{73}$. Władze III Rzeszy rozpowszechniały pacyfistyczny przekaz, że niesprawiedliwe ustalenia Konferencji Rozbrojeniowej są zalążkiem przyszłego konfliktu zbrojnego. Hitler i jego zwolennicy wmawiali opinii publicznej, że ze względu na pragnienie życia w pokoju i przyjaźni z innymi narodami podjęli decyzję o wystąpieniu z Ligii Narodów i porzucili Konferencję Rozbrojeniową. Henri Golay, sekretarz generalny i wydawca czasopisma „The Peace Movement", uznał za konieczne podziękowanie Hitlerowi za tak szczerą i szlachetną postawę oraz zamieścił w piśmie list gratulacyjny. Henri La Fontaine, przewodniczący Międzynarodowego Biura Pokoju, nie podzielał entuzjazmu Golaya, jednak nie sprzeciwił się publikacji napisanego $\operatorname{listu}^{74}$. Hitler, posługując się pacyfistyczną

${ }^{70}$ M. Leczyk, Paneuropa Coudenhove-Kalergiego (Narodziny idei), „Mazowieckie Studia Humanistyczne" 2002, nr 2, s. 190.

${ }_{71}$ A. Bullock, Hitler. Studium tyranii, thum. T. Evert, Warszawa 1997, s. 287.

${ }^{72}$ Ibidem, s. 273-274.

${ }^{73}$ Niemcy wystapity z Ligii Narodów. Komplikacja jakiej świat nie znat..., „Echo” 1933, nr 285, s. 1.

${ }^{74} \mathrm{~V}$. Rauzier, Logiques nationales, internationales et identitaires : une histoire du pacifisme du Bureau International de la Paix dans l'entre-deux guerres, s. 62-63, https://dumas.ccsd.cnrs.fr/dumas-00424137/document [dostęp: 20 V 2021 r.]. 
sofistyką, w którą zapewne ufał niejeden Brytyjczyk i Francuz, skutecznie realizował wyznaczone sobie cele polityczne.

Wielu na Zachodzie postrzegało jako obrońcę pokoju także ZSRR. Związkowi Sowieckiemu o to właśnie chodziło - ukazać, że misją ojczyzny światowego proletariatu jest powstrzymanie wybuchu wojny. Od 1927 roku Stalin, a za nim zainstalowani w krajach Europy Zachodniej poplecznicy głosili, że tylko antymilitaryzm komunistycznych partii przyczynia się do utrzymania pokoju. Pod koniec lat 20. ze Związku Sowieckiego do społeczeństw Zachodu płynął przekaz, że jedynie strach Europy przed Związkiem Sowieckim sprawił, że kraje kapitalistyczne nie zaczęły jeszcze z sobą walczyć ${ }^{75}$. Sprytnie pomyślany spektakl propagandowy, który przedstawiał narodom świata Związek Sowiecki jako wielkiego orędownika pokoju, rozpoczął się 18 września 1934 roku. Tego dnia nastąpiło przyjęcie ZSRR do Ligi Narodów, a w inauguracyjnym przemówieniu komisarz Maksim Litwinow stwierdził, że najważniejszym celem jest osiągnięcie pokoju ${ }^{76}$. Wielu polityków obecnych w Genewie przyjęło takie deklaracje z rezerwą, ale pacyfiści z Zachodu wiązali z nimi duże nadzieje. Oto wielkie proletariackie państwo bezinteresownie broniło światowego pokoju.

Zachodnie organizacje pacyfistyczne i antymilitarystyczne idealnie nadawały się do krzewienia „walki o pokój”. Komintern był tego świadomy. Propagandziści sowieccy dobrze wyczuwali antywojenne nastroje Europy Zachodniej. Francuscy, a zwłaszcza angielscy pacyfiści pokazali niechęć dla walczącej w 1920 roku z Rosją bolszewicką Polski. Zachodni antymilitaryzm był natomiast ceniony jako skuteczne narzędzie w rękach Kremla rozkładającego armie Europy Zachodniej. Przedstawiciele Międzynarodówki Komunistycznej przewodzili lub odgrywali kluczową rolę na większości kongresów pacyfistycznych. Kilka miesięcy przed wybuchem II wojny światowej ten mechanizm dokładnie przeanalizował Arnold Jaskowski: „Komintern odniósł duże sukcesy we Francji, Belgii, Austrii, a nawet Anglii, gdzie propaganda pacyfistyczna prowadzona była wśród rekrutów, rezerwistów, młodzieży z kół inteligenckich, a nawet wśród składu kadrowego armii regularnej i floty. Komuniści wydają tam szereg pism, które są rozpowszechniane wśród żołnierzy i marynarzy"77. $\mathrm{Na}$ polecenie Kominternu komuniści osłabiali armie niemal we wszystkich europejskich państwach. Bazowano głównie na antymilitaryzmie i pacyfizmie, które pojawiły się po I wojnie światowej. Wykorzystywano lokalną niechęć do służby wojskowej i zakorzenioną $\mathrm{w}$ wielu regionach od pokoleń tradycję ukrywania się przed poborem, a także sympatię okolicznej ludności do dezerterów. Tak właśnie działali w latach 20. i 30. przywódcy Parti communiste français, to jest Francuskiej Partii Komunistycznej (dalej PCF), a także jej młodzieżowej przybudówki z Mouvement Jeunes Communistes de France. Dużym rozgłosem cieszyły się antywojskowe manifestacje w garnizonie w Cherbourgu. W lipcu 1927 roku w tamtejszym porcie wojennym zebrało się

${ }^{75}$ T. Teslar, Czerwona gwiazda. Prawda o sowietach i komunizmie. Szkice aktualne, Warszawa 1928, s. 29.

${ }^{76}$ W. Balcerak, op. cit., s. 192.

77 A. Jaskow ski, Komintern a przyszła wojna, „Wschód. Orient. Kwartalnik Poświęcony Sprawom Wschodu" 1939, nr 1 (31), s. 36. 
około 600 rezerwistów, którzy ruszyli przez miasto, krzycząc: „Precz z ćwiczeniami wojskowymi!”, „Żądamy chleba dla naszych żon!”78. Do jeszcze większych protestów dochodziło w wioskach Nowej Akwitanii. W tym regionie już w 1926 roku francuscy komuniści zorganizowali wiele manifestacji poborowych przeciwko armii. W latach 30. odbyły się kolejne, liczniejsze. PCF prowadziła je pod hasłami sprzeciwu wobec wydłużenia obowiązkowej służby wojskowej do dwóch lat. Kulminacją były wydarzenia z 3 czerwca 1935 roku: kilkaset osób zebrało się przed ratuszem w miejscowości Seilhac, a dwieście pięćdziesiąt wdarło się do środka budynku, gdzie pracowała komisja poborowa. Z ratusza szybko wyrzuciła ich policja, ale przybyłego do Seilhac prefekta Tulle przywitał tłum z czerwonymi flagami i okrzykami: „Wszędzie Sowiety!”, „Precz z wojną!”, „Precz z dwuletnią służbą wojskową!”79. Jak zauważył Laird Boswell, amerykański historyk specjalizujący się w dziejach Francji, na początku lat 30. nastroje na wiejskich obszarach Francji pogorszył poważny kryzys w rolnictwie. Proponowane wydłużenie służby wojskowej dało nowe życie antymilitaryzmowi, co w Nowej Akwitanii nie było trudne. Departament Corrèze miał bowiem od XVIII wieku i jeszcze długo potem najwyższy we Francji wskaźnik dezercji. W tych odosobnionych górskich terenach mieszkańcy mobilizowali się do obrony dezerterów i ukrywania poborowych. Antymilitarystyczne nastroje wzmocniła I wojna światowa. Od lat 30. pobór do wojska był otwarcie krytykowany. Jak zauważył Boswell: „O ile jednak w dawnych wiekach opór przed poborem był tradycyjnym sposobem życia, w XX wieku miał znacznie bardziej polityczny charakter, był związany z wiejskim pacyfizmem, do którego komuniści zręcznie zachęcali”"80.

\section{ZAKOŃCZENIE}

Dziesiątki stowarzyszeń na rzecz pokoju i tysiące popierających je osób w Europie Zachodniej były nadzieją, że tragedia lat 1914-1918 nigdy się nie powtórzy. Wydawało się, że pacyfiści organizujący wielkie kongresy, coraz radykalniejsi antymilitaryści, pisarze i związkowcy, a nawet potępiający instytucję armii byli wojskowi to potężna siła. Ruch pacyfistyczny w międzywojennej Europie Zachodniej okazał się jednak kolosem na glinianych nogach. Pacyfiści byli zupełnie bezradni wobec światowych zbrojeń, a także wojen, które rozgorzały do czasu wybuchu tej największej w 1939 roku. Słabość pacyfistów przejawiała się w podziałach ideologicznych ruchu (organizacje komunistyczne i chrześcijańskie) oraz błędnych ocenach zachodzących w świecie wydarzeń. Antymilitaryści swoim radykalizmem (negacja służby wojskowej) skutecznie odstraszyli wiele osób przychylnych ruchom antywojennym.

Brytyjski appeasement $\mathrm{i}$ fakt, że w latach 30 . trwałym elementem życia społeczno-politycznego Francji stał się pacyfizm, był wyjątkowym prezentem dla Hitlera. Wódz

\footnotetext{
78 Antymilitarne demonstracje, „Życie Robotnicze” 1927, nr 30, s. 1.

${ }^{79}$ L. Boswel1, Rural Communism in France 1920-1939, New York 1998, s. 147.

${ }^{80}$ Ibidem, s. 148 (cyt. w art. - tłum. R.K.).
} 
III Rzeszy ochoczo korzystał z ustępliwości polityków brytyjskich i niezdecydowania przedstawicieli Francuzów. Wielką Brytanię oraz Francję winić można za brak stanowczości wobec narodowosocjalistycznych Niemiec. Rządy dwóch europejskich mocarstw wolały schlebiać nastrojom pacyfistycznym rodzimych społeczeństw, niż zaostrzyć kurs polityczny wobec Hitlera i być może zmienić losy Europy w 1939 roku. Idealizm przeciwników wojny i niechęć młodych Francuzów i Anglików do służby wojskowej skwapliwie wykorzystał także Komintern. Z tej naiwności zachodnich pacyfistów ZSRR zrobił użytek również po 1945 roku, ale to jest już odrębny temat rozważań.

\section{BIBLIOGRAFIA}

\section{Archiwa i zespoły archiwalne}

Archiwum Akt Nowych

Ambasada Polska w Paryżu

Ambasada Rzeczypospolitej Polskiej w Berlinie

Prasa (do 1939 r.)

„Echo” (1933)

„Goniec Śląski” (1928)

„Wolnomyśliciel” (1935)

„Wschód. Orient. Kwartalnik Poświęcony Sprawom Wschodu” (1939)

„Życie Robotnicze” (1927)

\section{Czasopisma naukowe i popularnonaukowe (po 1945 r.)}

„Acta Universitatis Lodziensis” 1986, t. 28

„Dzieje Najnowsze” 1980, nr 2, t. 12, 2009, nr 3, t. XLI

„exilOgraph" (2009)

Le pacifisme en Allemagne Du Reich wilhelmien à la fin de la République de Weimar (18901933), red. A. Dupeyrix, „Revue Les cahiers Irice” 2011, nr 8, t. 2

„Mazowieckie Studia Humanistyczne” (2002)

„Soldaten sind Mörder”. Dokumentation einer Debatte 1931-1996, red. M. Hepp, V. Otto, Christoph Links Verlag, Berlin 1996

„Vierteljahrshefte für Zeitgeschichte” (1985)

„Workers of the World: International Journal on Strikes and Social Conflict”, t. I, nr 6, 2016 


\section{Wspomnienia, pamiętniki, literatura piękna, teksty źródłowe i okolicznościowe}

Bloch M., Dziwna klęska, tłum. K. Marczewska, Warszawa 2008.

Céline L.-F., Podróż do kresu nocy, tłum. O. Hademan, Izabelin 2005.

Dyboski R., Anglia po wojnie. Wrażenia i refleksje, Kraków 1924.

E.M. Remarque. Wojujacy pacyfista. Artykuty $i$ wywiady 1929-1966, wybór i wstęp

T.F. Schneider, tłum. W. Kunicki, Warszawa 1998.

Glaeser E., Ostatni cywil, tłum. P. Hulka-Laskowski, Warszawa 1938.

Glaeser E., Pokój, tłum. M. Was sermanówna, Warszawa 1933.

Hitler A., Mein Kampf. Moja Walka. Edycja krytyczna. Z języka niemieckiego przełożył, wstępem, przypisami i bibliografią selektywną opatrzył E.C. Król, Warszawa 2020.

Mann T., Moje czasy, wybór i wstęp H. Orłowski, tłum. W. Kunicki, Poznań 2002.

Manstein von E., Żotnierskie życie. Moja stużba w Reichswehrze i Wehrmachcie 19191939, Kraków 2013.

Musil R., Człowiek bez właściwości, t. 2, tłum. K. Radziwiłł, K. Tuchanowski, J. Zeltzer, Warszawa 2002.

Russell B., Autobiografia 1914-1944, thum. A. Podzielna, Warszawa 1998.

Światowy Kongres Pokoju w Brukseli. Nakładem Komitetu Obrony Pokoju przy Lidze Obrony Praw Człowieka i Obywatela, Oddział w Sosnowcu, 1936.

Wystawa Herman Stöhr - Stanisław Kubicki. Zginęli w tej samej sprawie, Szczecin, październik 2016.

Zweig A., Spór o sierżanta Grisze, tłum. W. Kragen, Warszawa 1997.

Zweig A., Wychowanie pod Verdun, tłum. W. Kragen, Warszawa 1977.

\section{Opracowania}

Balcerak W., Liga Nadziei. Z dziejów Ligi Narodów, Warszawa 2010.

Bauer L., Jutro znowu wojna, badanie teraźniejszości, rzut oka w przyszłość, thum. W. Rogowicz, Warszawa 1932.

Bock N., Pazifizmus zwischen Anpassung und ,freier Ordnung”, Friedensdiskussionen in

Weimarer Republik und die Gewaltfreiheitstheorie des holländischen Pazifisten Bart de Ligt (1883-1938), Hamburg 1991.

Boswell L., Rural Communism in France 1920-1939, New York 1998.

Brock P., de Ligt-Fonds B., Overdenkingen Bij Het Herlezen Van „La Paix Crétrice” Na

51 Jaar. Reflections on reading „La Paix Crétrice” after fifty-one years, Zwolle 1994.

Brock P., Young N., Pacifism in the Twentieth Century, Syracuse 1999.

Bullock A., Hitler. Studium tyranii, thum. T. Evert, Warszawa 1997.

Caedel M., Pacifism in Britain, 1914-45. Defining of a Faith, Oxford 1980.

Chalamet Ch., Revivalism and Social Christianity: The Prophetic Faith of Henri Nick and André Trocmé, Eugene 2013.

Chwalba A., Samobójstwo Europy. Wielka Wojna 1914-1918, Kraków 2014.

Devaldès M., Sprzeciw sumienia, tłum. A. Kurlandzka, Warszawa 1930.

Einstein A., Mój obraz świata, Warszawa 1935.

Fiedor K., Działalność organizacji pacyfistycznych w Europie na rzecz rozbrojenia i zachowania pokoju w okresie międzywojennym, „Acta Universitatis Lodziensis” 1986, t. 28.

Fiedor K., Militaryzmowi i faszyzmowi-nie. Carl von Ossietzky, życie i walka, WarszawaWrocław 1986. 
Fiedor K., Niemiecki ruch obrońców pokoju, Wrocław 1993.

French D., Armia Brytyjska 1919-1945, tłum. R. Majewski, Poznań 2014.

Jan Bloch, pacyfizm europejski $i$ wyobraźnia Wielkiej Wojny. Studia i rozważania, red. M. Kornat, Warszawa 2016.

Kochanowski P., Analiza realizacji polityki zagranicznej państwa na przykładzie Wielkiej Brytanii czasu II wojny światowej. Fakty i mity, Toruń 2018.

Kotłowski T., Historia Republiki Weimarskiej (1919-1933), Poznań 1997.

Kozaczuk W., Wehrmacht, Warszawa 2004.

Megargee G.P., The Army Before Last: British Military Policy, 1919-1939, and Its Relevance for the U.S Army Today, Santa Monica 2000.

Nichols B.J., Dzwon na trwoge, thum. W. Komarnicka, Warszawa 1934.

Nilsson A.T., ABC ruchu na rzecz pokoju. Daty i fakty, słowo wstępne T. Kotarbiński, Z. Nałkowska, Warszawa 1937.

Sierpowski S., Kondycja Stowarzyszeń Przyjaciół Ligi Narodów (1919-1939), Poznań 2018.

Sierpow ski S., Liga Narodów w latach 1919-1926, Wrocław-Warszawa-Kraków 2005.

Ślusarczyk J., Idea pokoju w europejskiej i polskiej myśli politycznej do 1939 roku, Warszawa 1995.

Teslar T., Czerwona gwiazda. Prawda o sowietach i komunizmie. Szkice aktualne, Warszawa 1928.

The Moot Papers: Faith, Freedom and Society 1938-1944, ed. K. Clements, New York 2010.

Zirkel K., Vom Militaristen zum Pazifisten: Politisches Leben und Wirken des Generals Berthold von Deimling vor dem Hintergrund der Entwicklung Deutschlands vom Kaiserreich zum Dritten Reich, Inaugural-Dissertation zur Erlangung des akademischen Grades eines Doktors der Philosophie (Dr. phil.) durch die Philosophische Fakultät der HeinrichHeine-Universität Düsseldorf 2006.

\section{Netografia}

Davis R., The British Peace Movement in the Interwar Years. Le Mouvement pacifiste britannique de l'entre-deux-guerres, „Revue Française de Civilisation Britannique. French Journal of British Studies” 2017, nr 3, https://journals.openedition.org/rfcb/1415. [dostęp: $14 \mathrm{~V} 2021 \mathrm{r}$.$] .$

Ingram N., The Politics of Dissent: Pacifism in France, 1919-1939, (wersja pracy doktorskiej), University of Edinburgh, Edinburg 1988, https://era.ed.ac.uk/handle/1842/6876 [dostęp: 18 V 2021 r.].

Kellner D., Ernst Friedrich's Pacifistic Anarchism, http://www.gseis.ucla.edu/faculty/kellner/kellner.html. [dostęp: 25 I 2016 r.].

Rauzier V., Logiques nationales, internationales et identitaires : une histoire du pacifisme du Bureau International de la Paix dans l'entre-deux guerres, https://dumas.ccsd.cnrs.fr/ dumas-00424137/document [dostęp: 20 V 2021 r.].

Royo J., British Military Decline 1919-1939, https://smallwarsjournal.com/jrnl/art/britishmilitary-decline-1919-1939 [dostęp: 15 V 2021 r.]. 